\title{
An Oxidoreductive Pathway for D-Xylose Assimilation by Rhodosporidium toruloides
}

\author{
By IRMA SUOMALAINEN, * JOHN LONDESBOROUGH AND \\ MATTI KORHOLA \\ Research Laboratories, Alko Ltd, POB 350, SF-00101 Helsinki, Finland
}

(Received 1 December 1988; accepted 7 February 1989)

\begin{abstract}
Extracts of Rhodosporidium toruloides grown aerobically on xylose contained xylitol dehydrogenase and D-xylose reductase activities. Extracts of cells grown on glucose contained one-tenth as much xylose reductase and no detectable xylitol dehydrogenase. The xylitol dehydrogenase was purified to near homogeneity, and is a tetramer of $45 \mathrm{kDa}$ subunits. This labile enzyme could be stabilized by glycerol $(25 \%)$ and was rapidly inactivated by $10 \mathrm{~mm}$-EDTA. It catalyses the reversible, NAD ${ }^{+}$-dependent oxidation of xylitol to xylulose. Apparent $K_{\mathrm{m}}$ values are $19 \mathrm{mM}$ xylitol and $0 \cdot 3 \mathrm{mM}^{-N A D^{+}}$at $30^{\circ} \mathrm{C}, \mathrm{pH} 8.5$. Partially purified preparations of xylose reductase catalysed the NADPH-dependent reduction of D-xylose to xylitol, and were 16 times as active with $33 \mathrm{~mm}$-DL-glyceraldehyde as with $33 \mathrm{~mm}$-D-xylose. Apparently $R$. toruloides grown on xylose has the necessary enzymes to convert xylose to xylulose by the oxidoreductive pathway.
\end{abstract}

\section{INTRODUCTION}

The assimilation of $\mathrm{D}$-xylose by bacteria usually involves its direct isomerization to $\mathrm{D}$-xylulose by xylose isomerase (EC 5.3.1.5). This pathway has also been proposed for two yeasts, Rhodosporidium toruloides (Höfer et al., 1971) and Candida utilis (Tomoyeda \& Horitsu. 1964); more recently, xylose isomerase has been purified from the yeast Candida boidinii (Vongsuvanlert \& Tani, 1988b). However, in eukaryotic micro-organisms, including yeasts, xylose is usually reduced to xylitol by a pyridine nucleotide-linked D-xylose reductase, and the xylitol is then oxidized to xylulose by a xylitol dehydrogenase (Chiang \& Knight, 1960; Veiga, $1968 a, b$; Sugai \& Veiga, 1981; Smiley \& Bolen, 1982; Suihko et al., 1983; Bruinenberg et al., 1984). In C. utilis, the enzymes of this oxidoreductive pathway appear to coexist with the isomerase (Horitsu \& Tomoeda, 1966; Horitsu et al., 1968).

Here we describe the purification to near homogeneity and characterization of an $\mathrm{NAD}^{+}$linked xylitol dehydrogenase from $R$. toruloides. NADPH-linked xylose reductase activity was also demonstrated. Thus, this red, lipid-forming yeast, which grows readily on D-xylose in aerobic conditions, appears to have the enzyme equipment needed to assimilate xylose by the oxidoreductive pathway.

\section{METHODS}

Organism and cultivation conditions. The yeast strain used was Rhodosporidium toruloides ATCC 26194 (earlier called Rhodotorula gracilis 5/Fres/Harrison). The cultivation medium was $0.67 \%$ yeast nitrogen base (Difco) with $4 \%(\mathrm{w} / \mathrm{v})$ D-xylose, $4 \%(\mathrm{w} / \mathrm{v}) \mathrm{D}$-glucose, $4 \%(\mathrm{w} / \mathrm{v})$ xylitol or $2 \%(\mathrm{w} / \mathrm{v})$ ethanol as carbon source. The yeast was grown at $30^{\circ} \mathrm{C}$ on a rotary shaker at 200 r.p.m. Inocula for D-xylose and xylitol cultivations were grown on D-xylose and those for D-glucose and ethanol cultivations on D-glucose or ethanol, respectively. The residual sugar transferred to cultivations with the inocula was less than $0.05 \%(w / v)$. Growth was estimated with a KlettSummerson colorimeter $(600 \mathrm{~nm}$ filter) or a Coulter counter.

Enzyme assays. Xylitol dehydrogenase and xylose reductase were assayed at $30^{\circ} \mathrm{C}$ and $340 \mathrm{~nm}$ with a recording spectrophotometer. Standard xylitol dehydrogenase assays contained $0.1 \mathrm{M}-\mathrm{Tris} / \mathrm{HCl}, \mathrm{pH} 8.5,33 \mathrm{~mm}-\mathrm{xylitol}$ and $0 \cdot 3 \mathrm{~mm}-\mathrm{NAD}^{+}$. Standard xylose reductase assays contained $0 \cdot 1 \mathrm{M}$-potassium phosphate, $\mathrm{pH} 6 \cdot 0,33 \mathrm{~mm}-\mathrm{xylose}$ and 
$0.12 \mathrm{~mm}$-NADPH. Assays were usually started by addition of substrate after observing any blank reaction for a few minutes. One unit (U) of each enzyme catalyses the reduction (or oxidation) of $1 \mu \mathrm{mol} \mathrm{NAD}{ }^{+}$(or NADPH) $\min ^{-1}$ under these standard conditions. Other conditions are described in Results.

Protein assays. Protein was determined by the methods of Warburg \& Christian (1941) or Bradford (1976). The Bradford (1976) method was standardized with ovalbumin.

Preparation of cell extracts. Cells were harvested by centrifugation in a cold rotor, and all subsequent steps done at 0 to $8^{\circ} \mathrm{C}$. Cells (about $10 \mathrm{~g}$ fresh wt) were washed twice with the appropriate buffer (see below), suspended in the same buffer to a final volume of $20 \mathrm{ml}$, mixed with $27 \mathrm{ml}$ of $0.5 \mathrm{~mm}$ diameter glass beads and shaken five times for $1 \mathrm{~min}$ in a Braun MK II homogenizer. The beads were removed with a G1 sinter and the disintegrated yeast centrifuged for $20 \mathrm{~min}$ at $28000 \mathrm{~g}$. The resulting supernatant was used for enzyme and metabolite assays (xylitol dehydrogenase and xylose reductase could not be detected in the sediment).

Purification of xylitol dehydrogenase. Yields (U) and specific activities [U (mg protein) ${ }^{-1}$ ] are shown in parentheses after each step.

Step 1. $R$. toruloides $(9.7 \mathrm{~g}$ fresh wt) grown on xylose was suspended in TEMD buffer $(25 \mathrm{mM}-\mathrm{Tris} / \mathrm{HCl}$, pH 7.5/0.1 mM-EDTA/1 mM- $\mathrm{MgCl}_{2} / 1 \mathrm{~mm}$-dithiothreitol) containing PMSF ( $\left.1 \mathrm{mM}\right)$ and pepstatin A $\left(10 \mu \mathrm{g} \mathrm{ml}^{-1}\right)$ and disintegrated as described above. Further PMSF $(0.4 \mathrm{mM})$ and pepstatin $\mathrm{A}\left(4 \mu \mathrm{g} \mathrm{ml}^{-1}\right)$ were added to the $28000 \mathrm{~g}$ supernatant $\left(23 \mathrm{ml}, 30 \mathrm{U}, 0.04 \mathrm{U} \mathrm{mg}^{-1}\right)$.

Step 2. $\left(\mathrm{NH}_{4}\right)_{2} \mathrm{SO}_{4}(6 \cdot 2 \mathrm{~g})$ was added to $22 \mathrm{ml}$ of the $28000 \mathrm{~g}$ supernatant, and after $20 \mathrm{~min}$ the precipitated protein was removed by centrifugation. A further $3.7 \mathrm{~g}$ of $\left(\mathrm{NH}_{4}\right)_{2} \mathrm{SO}_{4}$ was added to the supernatant. After $20 \mathrm{~min}$, the precipitated protein was collected by centrifugation $(10 \mathrm{~min}, 28000 \mathrm{~g})$ and suspended in TEMD containing $25 \%$ (v/v) glycerol (TEMD/glycerol). PMSF ( $1 \mathrm{mM})$ and pepstatin A $\left(10 \mu \mathrm{g} \mathrm{ml}^{-1}\right)$ were added and insoluble material removed by centrifugation $\left(2 \cdot 1 \mathrm{ml}, 22.5 \mathrm{U}, 0.26 \mathrm{U} \mathrm{mg}^{-1}\right)$.

Step 3. The supernatant was passed through a $15 \times 50 \mathrm{~mm}$ column of Sephadex G25 equilibrated with TEMD/glycerol and applied to a $9 \times 70 \mathrm{~mm}$ column of NAD ${ }_{-}(\mathrm{C} 8)$-agarose (Sigma). The column was washed at $15 \mathrm{ml} \mathrm{h}^{-1}$ with, sequentially, $20 \mathrm{ml} \mathrm{TEMD} /$ glycerol, $20 \mathrm{ml} \mathrm{TEMD} /$ glycerol $/ 0 \cdot 1 \mathrm{M}-\mathrm{KCl}, 2 \mathrm{ml} \mathrm{TEMD} / \mathrm{glycerol}$ and $12 \mathrm{ml} \mathrm{TEMD} /$ glycerol $/ 0.5 \mathrm{~mm}-\mathrm{NAD}^{+}$. The enzyme was then eluted at $7 \mathrm{ml} \mathrm{h}^{-1}$ with TEMD/glycerol/3.4 mM$\mathrm{NAD}^{+}\left(9 \cdot 3 \mathrm{ml}, 11 \cdot 6 \mathrm{U}, 15 \cdot 4 \mathrm{U} \mathrm{mg}^{-1}\right)$.

Step 4. The eluate was applied to a $7 \times 75 \mathrm{~mm}$ column of DE52-cellulose (Whatman) equilibrated with TEMD/glycerol. The column was washed at $11 \mathrm{ml} \mathrm{h}^{-1}$ with $50 \mathrm{ml} 0 \cdot 1 \mathrm{M}$ Tris/HCl, pH 7.5/0.1 mM-EDTA/1 mM$\mathrm{MgCl}_{2} / 1 \mathrm{mM}$-dithiothreitol $/ 25 \%$ glycerol and the enzyme eluted with $0.3 \mathrm{M}-\mathrm{KCl}$ in this buffer $(1.4 \mathrm{ml}, 2.3 \mathrm{U}$, 12.2 $\mathrm{U} \mathrm{mg}^{-1}$ ).

Partial purification of xylose reductase. Xylose reductase from cells grown on xylose was studied using enzyme partially purified as follows. The cells $(8.1 \mathrm{~g})$ were suspended in TED buffer, $\mathrm{pH} 7.5$, $(25 \mathrm{mM}-\mathrm{Tris} / \mathrm{HCl}$, $\mathrm{pH} 7 \cdot 5 / 0 \cdot 1 \mathrm{mM}-\mathrm{EDTA} / 1 \mathrm{mM}$-dithiothreitol) containing $1 \mathrm{~mm}$-PMSF, and disintegrated and centrifuged as

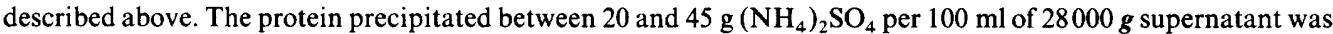
suspended in $1.7 \mathrm{ml} \mathrm{TED} \mathrm{(pH} \mathrm{7.5)} \mathrm{and} \mathrm{passed} \mathrm{sequentially} \mathrm{through} \mathrm{columns} \mathrm{of} \mathrm{Sephadex} \mathrm{G25} \mathrm{(15} \times 50 \mathrm{~mm}$ ) and DE52-cellulose $(14 \times 135 \mathrm{~mm})$ equilibrated with TED $(\mathrm{pH} \mathrm{7.5)}$.

This procedure was modified in order to compare the enzyme from cells grown on xylose, glucose or ethanol. The cells were broken as described above and the $28000 \mathrm{~g}$ supernatants dialysed overnight against TED (pH 7.5) to remove compounds that interfere with the assay. The dialysed supernatants from about $3.5 \mathrm{~g}$ of cells were again centrifuged at $28000 \mathrm{~g}$, passed through Sephadex G25 equilibrated with TED (pH 8.5) and loaded onto a DE52cellulose column $(14 \times 135 \mathrm{~mm})$ equilibrated with TED (pH 8.5). At this $\mathrm{pH}$ the enzyme bound to the column and was eluted at $24 \mathrm{ml} \mathrm{h}^{-1}$ with a linear gradient of 0 to $0.5 \mathrm{M}-\mathrm{KCl}$ in $120 \mathrm{ml}$ TED (pH 8.5).

Native $M_{r}$ determinations. Purified xylitol dehydrogenase $(200 \mu \mathrm{l})$ was run at $5^{\circ} \mathrm{C}$ and $15 \mathrm{ml} \mathrm{h}^{-1}$ through a Superose 12 HR 10/30 FPLC column (Pharmacia) equilibrated with TEMD/glycerol containing $0 \cdot 1 \mathrm{M}-\mathrm{KCl}$. The enzyme in $0.7 \mathrm{ml}$ fractions was assayed. The column was calibrated in the same buffer with ferritin $(440 \mathrm{kDa})$, lactate dehydrogenase $(144 \mathrm{kDa})$, bovine serum albumin $(68 \mathrm{kDa})$, ovalbumin $(43 \mathrm{kDa})$, myoglobin $(17 \cdot 2 \mathrm{kDa})$ and cytochrome $c(11 \cdot 7 \mathrm{kDa})$.

Electrophoresis. SDS-PAGE was done by the method of Laemmli (1970) with a linear gradient from $13 \%$ to $7 \%$ $(\mathrm{w} / \mathrm{v})$ acrylamide in the separator gel and a $3.7 \%(\mathrm{w} / \mathrm{v})$ stacker gel. Discontinuous electrophoresis of native samples was done, at $8{ }^{\circ} \mathrm{C}$, in the same system except that 2 -mercaptoethanol and SDS were replaced by $20 \%$ (v/v) glycerol. Continuous native electrophoresis was done in the same way except that samples and stacker gels both contained $75 \mathrm{~mm}-\mathrm{Tris} / \mathrm{HCl}$, pH 8.8/20\% glycerol (the separator gel buffer was $375 \mathrm{~mm}$-Tris/ $\mathrm{HCl}$, pH 8.8).

Xylitol dehydrogenase activity was located by incubating the gels for $60 \mathrm{~min}$ at $25^{\circ} \mathrm{C}$ in $100 \mathrm{ml} 0 \cdot 1 \mathrm{M}$-Tris/ $\mathrm{HCl}$, pH 8.5, containing $50 \mathrm{mg} \mathrm{NAD}{ }^{+}, 10 \mathrm{mg}$ nitrobluetetrazolium, $2 \mathrm{mg}$ phenazinemethosulphate and $60 \mathrm{~mm}$-xylitol. Protein bands were located by fixing the gels with $50 \%(\mathrm{w} / \mathrm{v})$ trichloroacetic acid and staining with Coomassie blue.

Analysis of sugars and sugar alcohols. The $28000 \mathrm{~g}$ supernatants of cells broken in $0 \cdot 1 \mathrm{M}$-potassium phosphate $/ 5 \%$ glutathione, $\mathrm{pH} 7 \cdot 0$, were brought to $5 \%(\mathrm{w} / \mathrm{v})$ trichloroacetic acid and centrifuged for $15 \mathrm{~min}$ at $28000 \mathrm{~g}$. The 
supernatants were neutralized with $\mathrm{KOH}$, deionized by shaking with Amberlite MB-3 ion exchanger, filtered, and concentrated in vacuo at $40^{\circ} \mathrm{C}$.

Growth media were filtered through $0.2 \mu \mathrm{m}$ Millex filters (Millipore) to remove cells, and deionized with Amberlite MB-3.

The product of the xylitol dehydrogenase reaction was formed by adding $15 \mu \mathrm{l}(23 \mathrm{mU})$ of purified (step 4) xylitol dehydrogenase to $3 \mathrm{ml} 2.9 \mathrm{~mm}-\mathrm{LiNAD} / \mathrm{KOH}, \mathrm{pH} 8 \cdot 6$, containing $33 \mathrm{~mm}$-xylitol. Buffer and glycerol were omitted because they interfered with HPLC analyses. Over $6 \mathrm{~h}$ incubation at $30^{\circ} \mathrm{C}$ a further $3 \cdot 1 \mathrm{mM}-\mathrm{LiNAD}$ was added as solid. The pH fell to 6.9 .

The product of the xylose reductase reaction was formed by adding $0.3 \mathrm{ml}(152 \mathrm{mU})$ xylose reductase (DE-52 eluate at $\mathrm{pH} 7 \cdot 5$, specific activity $70 \mathrm{mU} \mathrm{mg}^{-1}$ ) to $2.7 \mathrm{ml} 0.1 \mathrm{M}$-potassium phosphate, $\mathrm{pH} 6 \cdot 0$, containing $1.0 \mu \mathrm{mol}$ NADPH and $33 \mathrm{~mm}$ xylose. Over $5 \mathrm{~h}$ incubation at $30^{\circ} \mathrm{C}$ a further $7 \mu \mathrm{mol} \mathrm{NADPH}$ was added (final volume $3.5 \mathrm{ml}$ ).

Blank reaction mixtures lacking enzyme or substrate were handled in a similar way.

All samples were then filtered through SepPak C18-cartridges (Waters). HPLC analysis at $85^{\circ} \mathrm{C}$ was done (cell extracts, growth media and reaction mixtures) on a $300 \times 1.8 \mathrm{~mm}$ Resolution Carbohydrate $\mathrm{Ca}^{2+}$ column developed with water at $0.5 \mathrm{ml} \mathrm{min}{ }^{-1}$ or (cell extracts only) on a $150 \times 4.6 \mathrm{~mm}$ Nucleosil $5 \mathrm{NH}_{2}$ column developed with acetonitrile/water $(82.5: 17.5, \mathrm{v} / \mathrm{v})$ at $0.8 \mathrm{ml} \mathrm{min} \mathrm{min}^{-1}$. Eluted compounds were detected refractometrically and identified by comparison with standard sugars and sugar alcohols. Except for D-xylulose, these standards were from Alltech.

Materials. D-Xylulose was from Sigma (product X-4625). For growth media, D-glucose, D-xylose and xylitol were Art 8337, Art 8692 and Art 8666, respectively, from Merck. Standard proteins, ancillary enzymes and coenzymes were from Sigma or Boehringer. Other reagents were analytical grade or from sources stated in the text.

\section{RESULTS}

\section{Xylitol as a carbon source and metabolite of xylose}

Fig. 1 shows that $R$. toruloides grows as rapidly on $4 \%$ xylitol as on $4 \%$ xylose, and that during the phase of rapid growth the two carbon sources were used at similar rates $(0.34 \mathrm{~g}$ xylose and $0.29 \mathrm{~g}$ xylitol $\left.\mathrm{l}^{-1} \mathrm{~h}^{-1}\right)$. In both cases, rapid growth ceased before the carbon source was consumed and at similar cell densities $\left(0.9 \times 10^{8}\right.$ cells ml ${ }^{-1}$ for xylose and $1.3 \times 10^{8}$ cells ml $^{-1}$ for xylitol). A striking difference between the cultivations was the longer lag phase before rapid growth on xylose, although the inocula for the cultivations were identical samples of cells grown on xylose.

Extracts of cells grown to late exponential phase on xylose contained xylose ( $23 \mathrm{~mm}$ ), xylitol $(14 \mathrm{mM}$ ) and xylulose $(6 \mathrm{mM})$. Concentrations were calculated assuming $0.5 \mathrm{ml}$ cytosol per $\mathrm{g}$ fresh wt of cells. No attempt was made to stop metabolism rapidly. The results show that xylose appears in the cells and is converted to xylitol as well as xylulose. Arabitol $(0.25 \%)$ and xylitol $(0.05 \%)$ were found in the growth media after $102 \mathrm{~h}$ cultivation on xylose.

\section{Changes in oxidoreductase activities with carbon source}

The amounts of xylitol dehydrogenase and xylose reductase in cells grown to late exponential phase on different carbon sources are shown in Table 1. The activities of both enzymes were much higher with xylose as carbon source. Similar results were obtained with cell extracts concentrated in a Minicon concentrator, which removed molecules smaller than $15 \mathrm{kDa}$. During growth on xylose, the specific activity of xylitol dehydrogenase was highest in early exponential phase and decreased by about $40 \%$ by late exponential phase (not shown). In contrast, the specific activity of mannitol dehydrogenase (assayed by replacing the xylitol in the standard assay with $33 \mathrm{~mm}$-mannitol) increased about 2 -fold between early and late exponential phase.

\section{Physical properties of xylitol dehydrogenase}

Enzyme purified through the $\left(\mathrm{NH}_{4}\right)_{2} \mathrm{SO}_{4}$ fractionation and dissolved in TED (pH 7.5) lost $80 \%$ of its activity in $24 \mathrm{~h}$ at $5{ }^{\circ} \mathrm{C}$. It could not be stabilized by $0.18 \mathrm{M}-\mathrm{NaCl}$ or $\mathrm{KCl}, 0.1 \mathrm{M}-$ potassium phosphate, $\mathrm{pH} 6.0$, or $0.1 \mathrm{M}-\mathrm{Tris} / \mathrm{HCl}, \mathrm{pH} 8 \cdot 1$. Addition of $40 \%(\mathrm{w} / \mathrm{v})$ glycerol preserved $90 \%$ of the activity for $24 \mathrm{~h} . \mathrm{MgCl}_{2}(9 \mathrm{mM})$ did not affect the stability, but $9 \mathrm{mM}-$ EDTA caused $95 \%$ inactivation within $30 \mathrm{~min}$ at $0{ }^{\circ} \mathrm{C}$. Adding $3 \mathrm{~mm}$-EDTA to assay mixtures 


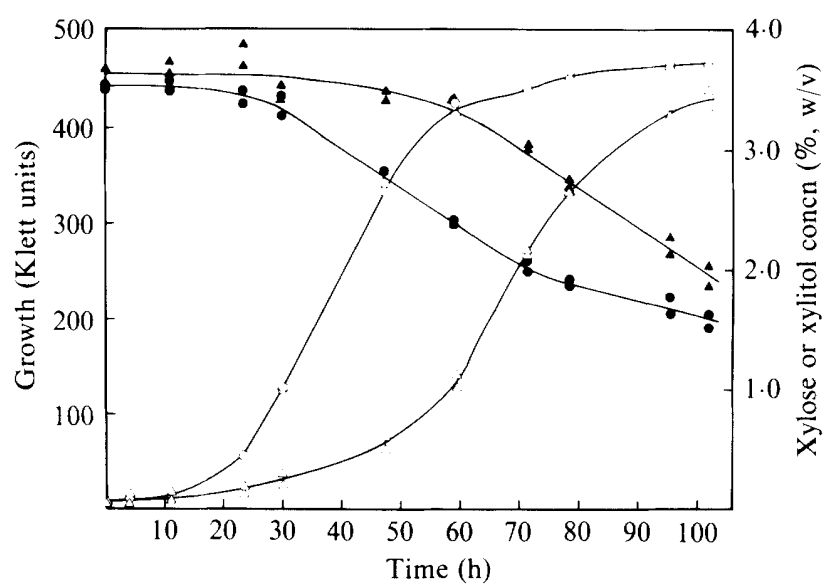

Fig. 1. Growth (open symbols) and consumption of xylose or xylitol (closed symbols) by $R$. toruloides grown on YNB/xylose $(\triangle, \Delta)$ or YNB/xylitol $(O,-)$. Growth was followed with a Klett-Summerson colorimeter and xylose and xylitol determined by HPLC as described in Methods.

Table 1. Xylose reductase and xylitol dehydrogenase from cells grown on different carbon sources

R. toruloides grown on $4 \%(\mathrm{w} / \mathrm{v})$ xylose, $4 \%(\mathrm{w} / \mathrm{v})$ glucose or $2 \%(\mathrm{w} / \mathrm{v})$ ethanol to about $5 \times 10^{7}$ cells $\mathrm{ml}^{-1}$ was harvested and cell extracts made in TED (pH 7.5) as described in Methods. Enzymes were assayed in the dialysed $28000 \mathrm{~g}$ supernatant.

$\begin{array}{lcc}\begin{array}{c}\text { Carbon } \\ \text { source }\end{array} & \begin{array}{c}\text { Xylose reductase } \\ {\left[\mathrm{U}(\mathrm{g} \text { fresh wt cells })^{-1}\right]}\end{array} & \begin{array}{c}\text { Xylitol dehydrogenase } \\ \text { Xylose }\end{array} \\ \text { Glucose } & 0.96 & 1.9 \\ \text { Ethanol } & 0.095 & <0.06 \\ & 0.27 & <0.04\end{array}$

inhibited the enzyme by more than $30 \%$ within $2 \mathrm{~min}$. Mannitol dehydrogenase in the same samples was unaffected by EDTA and was stable in the absence of glycerol. Together with the opposite changes in specific activities of xylitol and mannitol dehydrogenases during growth on xylose (see above), this suggests that the major xylitol dehydrogenase of $R$. toruloides is distinct from its major mannitol dehydrogenase, and may be a metalloprotein.

During purification, the highest specific activity $\left(15.4 \mathrm{U} \mathrm{mg}^{-1}\right)$ of xylitol dehydrogenase was reached at step 3, and represents a 380 -fold purification with a $38 \%$ yield. Only $20 \%$ of the activity was recovered through the DE- 52 column of step 4 , and the specific activity fell to $12 \cdot 2 \mathrm{U} \mathrm{mg}^{-1}$. This product, which was used in subsequent studies, may contain some inactivated xylitol dehydrogenase protein.

SDS-PAGE showed a main protein band at $45 \pm 1 \mathrm{kDa}$ and a minor band at $59 \mathrm{kDa}$ (Fig. 2). Enzyme activity comigrated with the major protein band in both continuous (Fig. 3) and discontinuous (not shown) native electrophoresis systems. In gel-filtration on Superose 12 in TEMD/glycerol $/ 0 \cdot 1 \mathrm{M}-\mathrm{KCl}$, more than $90 \%$ of the applied activity was recovered in a symmetrical peak corresponding to a native molecular mass of $200 \pm 35 \mathrm{kDa}$. Probably, the native enzyme is a tetramer.

\section{Catalytic properties of xylitol dehydrogenase}

At $33 \mathrm{~mm}$-xylitol, $0.3 \mathrm{~mm}-\mathrm{NAD}^{+}$, purified xylitol dehydrogenase had a $\mathrm{pH}$ optimum between 7.5 and 8.5 in $\mathrm{Tris} / \mathrm{HCl}$ (not shown).

No significant activity was observed when $\mathrm{NAD}^{+}$in the standard assay was replaced by $0.3 \mathrm{~mm}$-NADP. With different sugar alcohols in the standard assay the following relative rates were observed: at $33 \mathrm{mM}$; xylitol, 100; D-sorbitol, 62; ribitol, 47; L-arabitol, 11; D-arabitol, $\leq 1$; 


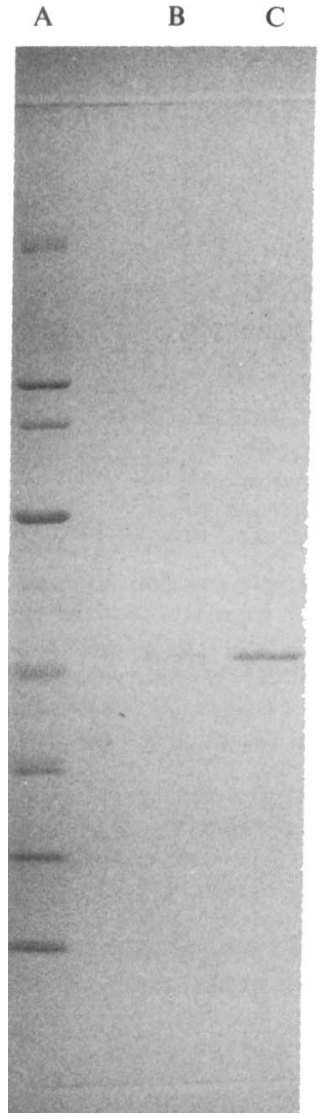

Fig. 2

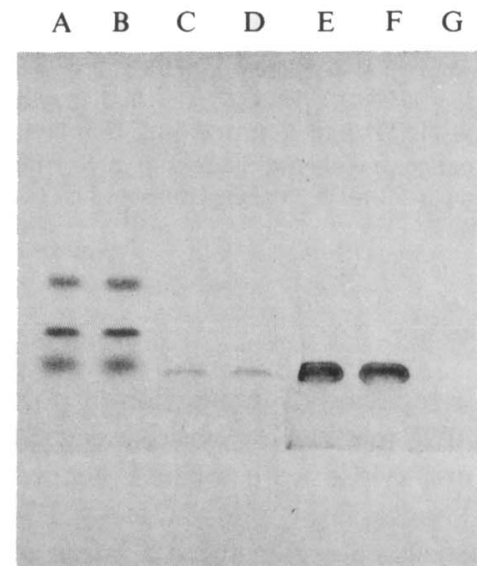

Fig. 3

Fig. 2. SDS-PAGE of xylitol dehydrogenase $\left(10 \mathrm{U} \mathrm{mg}^{-1}\right)$. Lanes $\mathrm{B}(0.8 \mu \mathrm{g})$ and $\mathrm{C}(2.8 \mu \mathrm{g})$ xylitol dehydrogenase. Lane $\mathrm{A}$, molecular mass markers [from top to bottom: myosin, $200 \mathrm{kDa} ; \beta$ galactosidase, $116 \mathrm{kDa}$; phosphorylase, $94 \mathrm{kDa}$; bovine serum albumin, $68 \mathrm{kDa}$; ovalbumin, $43 \mathrm{kDa}$; lactate dehydrogenase, $36 \mathrm{kDa}$; triose phosphate isomerase, $26.5 \mathrm{kDa}$; myoglobin, $17.2 \mathrm{kDa}$; and cytochrome $c, 11.7 \mathrm{kDa}$. (The latter two are coincident.)].

Fig. 3. Continuous native gel-electrophoresis of xylitol dehydrogenase. Lanes C, D, E and F, $1.7 \mu \mathrm{g}$ xylitol dehydrogenase $\left(10 \mathrm{U} \mathrm{mg}^{-1}\right)$. Lanes A, B, and $\mathrm{G}$, myoglobin $(2 \mu \mathrm{g})$, lactate dehydrogenase $(1 \mu \mathrm{g})$ and bovine serum albumin $(1 \mu \mathrm{g})$. Lanes $A$ to $D$ were stained for protein with Coomassie blue and lanes E to $G$ for xylitol dehydrogenase activity with nitroblue tetrazolium, as described in Methods.

D-mannitol, $\leq 1$; and erythritol, $\leq 1$. Glycerol at $3.3 \mathrm{M}$ gave $\leq 5 \%$ of the rate with $33 \mathrm{~mm}$-xylitol. DL-Dithiothreitol at $1 \mathrm{~mm}$ caused $85 \%$ inhibition. This may be related to the sugar alcohol structure of dithiothreitol, because $1.4 \mathrm{~mm}$-2-mercaptoethanol did not inhibit.

Purified enzyme lost about $50 \%$ of its activity when preincubated for $3 \mathrm{~min}$ at $30{ }^{\circ} \mathrm{C}$ in standard assay mixtures lacking xylitol or $\mathrm{NAD}^{+}$, and progress curves were very non-linear even when reactions were started with enzyme. Addition of $25 \%$ glycerol to standard assay mixtures decreased the initial rate by about $20 \%$ but caused the progress curves to be linear for at least $2 \mathrm{~min}$. Affinities for xylitol and $\mathrm{NAD}^{+}$were therefore measured in the presence of $25 \%$ glycerol. Hofstee plots were linear for xylitol with apparent Michaelis constants of $19 \mathrm{~mm}$ at 0.3 or $1.0 \mathrm{~mm}^{-N_{A D}}{ }^{+}$(Fig. $4 b$ ). At $33 \mathrm{~mm}$-xylitol, data between 3.7 and $0 \cdot 1 \mathrm{~mm}-\mathrm{NAD}^{+}$could be fitted satisfactorily by an apparent Michaelis constant of $0.33 \mathrm{~mm}$ but the Hofstee plot was detectably convex towards the origin (Fig. 4a). 


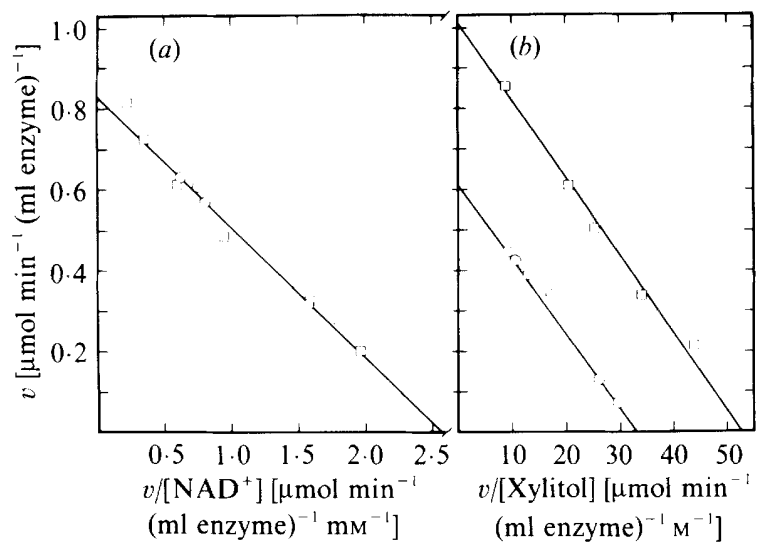

Fig. 4. Apparent Michaelis constants of xylitol dehydrogenase. Complete reaction mixtures (1 ml) contained $60 \mathrm{~mm}$-Tris $/ \mathrm{HCl}, \mathrm{pH} 8 \cdot 5,25 \%(\mathrm{v} / \mathrm{v})$ glycerol and substrates. In $(a)$ reactions were started by addition of $30 \mu \mathrm{l}$ xylitol $(O)$ or $10 \mu \mathrm{l}$ enzyme $(\square)$ to give, in both cases, final concentrations of $0 \cdot 1$ to $3.7 \mathrm{mM}^{-N A D^{+}}$and $33 \mathrm{~mm}$-xylitol. In $(b)$ reactions were started with xylitol $(O)$ or enzyme $(\square)$ to give final concentrations of 2.5 to $100 \mathrm{~mm}$-xylitol and either $0.3 \mathrm{~mm}(\mathrm{O})$ or $1.0 \mathrm{~mm}(\square) \mathrm{NAD}^{+}$. Lines are drawn for $V$ and $K_{\mathrm{m}}$ values computed by the direct linear plot method of Eisenthal \& Cornish-Bowden (1974).

Over a $6 \mathrm{~h}$ period of incubation of purified enzyme with $\mathrm{NAD}^{+}$and xylitol, as described in Methods, $0 \cdot 26$ mM-NAD ${ }^{+}$was reduced (according to $A_{340}$ measurements) and $0 \cdot 20 \mathrm{~mm}$-xylulose and $0.01 \mathrm{~mm}$-xylose were formed (according to HPLC analysis).

In $0.1 \mathrm{M}$-potassium phosphate, $\mathrm{pH} 7.0$, or $0.1 \mathrm{M}$-Tris $/ \mathrm{HCl}, \mathrm{pH} 8.5$, the purified xylitol dehydrogenase catalysed the oxidation of $0.27 \mathrm{~mm}-\mathrm{NADH}$ in the presence of xylulose (about $30 \mathrm{~mm}$ ) but not in the presence of xylose $(33 \mathrm{~mm})$, with a rate at $\mathrm{pH} 8.5\left[21 \mu \mathrm{mol} \mathrm{min}^{-1}(\mathrm{mg}\right.$ enzyme $\left.)^{-1}\right]$ greater than that $\left[13 \mu \mathrm{mol} \mathrm{m^{-1 }}\left(\mathrm{mg}^{2} \text { enzyme }\right)^{-1}\right]$ for the reduction of $0.27 \mathrm{~mm}-$ $\mathrm{NAD}^{+}$by $33 \mathrm{~mm}$-xylitol at $\mathrm{pH} 8.5$. We conclude the enzyme catalyses the reversible, NADHlinked reduction of xylitol to xylulose.

\section{Properties of xylose reductase}

During DE52-cellulose chromatography at $\mathrm{pH} 8.5$, as described in Methods, the xylose reductase activities from cells grown on xylose or glucose were recovered as single peaks at the same $\mathrm{KCl}$ concentration $(0 \cdot 1 \mathrm{M})$ with specific activities of 145 and $44 \mathrm{mU} \mathrm{mg}^{-1}$, respectively. Enzyme partially purified from xylose-grown cells by chromatography at $\mathrm{pH} 7.5$ (see Methods), was relatively stable $\left(90 \%\right.$ remained after $20 \mathrm{~h}$ at $5{ }^{\circ} \mathrm{C}$ in TED buffer) and was unaffected by 9 mM-EDTA. No significant activity was detected when NADPH was replaced by 0.12 mM$\mathrm{NADH}$ at either $\mathrm{pH} 6$ or $\mathrm{pH} 8 \cdot 5$. When D-xylose in the standard assay was replaced by other aldoses at $33 \mathrm{mM}$ the relative activities $(D-x y l o s e=100)$ were: DL-glyceraldehyde, 1600; L-arabinose, 140; DL-arabinose, 86; D-ribose, 70; and D-glucose, 28. At $0.3 \mathrm{mM}-\mathrm{NADPH}$, an apparent Michaelis constant of about $0 \cdot 2 \mathrm{M}$-xylose was deduced from measurements between 40 and $200 \mathrm{~mm}$-xylose (not shown).

During a $5 \mathrm{~h}$ incubation of partially purified enzyme with xylose and NADPH as described in Methods, $2.3 \mathrm{~mm}$-NADPH was oxidized $\left(\boldsymbol{A}_{340}\right.$ measurements) and $1.6 \mathrm{~mm}$-xylitol appeared (HPLC analyses). However, no reduction of NADP+ by the enzyme preparation $\left(7.8 \mathrm{mU} \mathrm{ml}^{-1}\right)$ was detected during incubations with $33 \mathrm{~mm}$-xylitol (at $\mathrm{pH} 6 \cdot 0,7 \cdot 0$ or $8 \cdot 1$ ), glycerol (at $\mathrm{pH} 6.0$, $7 \cdot 0,8 \cdot 1$ or $9 \cdot 0$ ) or sorbitol (at $\mathrm{pH} 6.0$ or $8 \cdot 5$ ). We conclude that the preparation contained an NADPH-linked D-xylose reductase that produces xylitol, and is effectively irreversible at these $\mathrm{pH}$ values. 


\section{DISCUSSION}

$R$. toruloides grows readily on xylose under aerobic conditions and has been reported (Höfer $e t$ al., 1971) to contain xylose isomerase (EC 5.3.1.5). Xylose isomerase is rare in eukaryotic micro-organisms, and efforts in this laboratory (P. Kristo, I. Suomalainen and M. Korhola, unpublished work) to demonstrate it in xylose-grown $R$. toruloides under a variety of conditions (including $\mathrm{Mg}^{2+}, \mathrm{Co}^{2+}$ or $\mathrm{Mn}^{2+}$ as activating cation, borate or other buffers, and use of fresh cell extracts or acetone powders prepared according to Höfer et al. (1971) have not succeeded. Possibly this represents a strain difference or some unexpected enzyme characteristic. Höfer $e t$ al. (1971) also reported that $R$. toruloides grown on $\mathrm{D}$-xylose did not respond to xylitol, whereas we found that it grew readily on xylitol (Fig. 1). We therefore tested whether $R$. toruloides contains the necessary enzymes for oxidoreductive conversion of D-xylose to D-xylulose via xylitol, and found that NADPH-linked xylose reductase and NAD-linked xylitol dehydrogenase were present in cells grown on xylose.

Determination of relatively small activities of these enzymes in undialysed cell extracts is complicated by blank and competing reactions caused by the presence of endogenous substrates of these and other dehydrogenases. The results with dialysed extracts (Table 1) probably underestimate xylitol dehydrogenase, which is not a stable enzyme, but allow comparisons to be made between cells grown on different carbon sources. The higher levels of both enzymes found in cells grown on xylose suggests that they are importantly involved in xylose utilization. Xylitol dehydrogenase could not be demonstrated in cells grown on glucose or ethanol, suggesting that its de novo synthesis may be induced by xylose, as has been shown for Pullularia pullulans (Sugai \& Veiga, 1988). The level of xylose reductase in ethanol-grown cells was about $30 \%$ of that in xylose-grown cells, and decreased further (to about $10 \%$ ) in glucose-grown cells (Table 1). Bicho et al. (1988) have shown that glucose prevents the appearance of xylose reductase in Pachysolen tannophilus and Pichia stipitis when these yeasts are grown on mixtures of xylose and glucose, and suggested that this may be due to catabolite repression by glucose.

The total amounts of xylose reductase and xylitol dehydrogenase found in $R$. toruloides grown aerobically on xylose are less than those reported for some xylose-fermenting yeast. Thus, Bolen et al. (1986) reported $47 \mathrm{mU}$ NADPH-linked xylose reductase (mg protein) ${ }^{-1}$ (at $50 \mathrm{~mm}$-xylose, $\mathrm{pH} 7.4,30^{\circ} \mathrm{C}$ ) and $140 \mathrm{mU} \mathrm{NAD}^{+}$-linked xylitol dehydrogenase (mg protein) ${ }^{-1}$ (at $50 \mathrm{mM}^{-}$ xylitol, $\mathrm{pH} 8.6,30^{\circ} \mathrm{C}$ ) in cell extracts of $P$. tannophilus grown on xylose. Under our assay conditions we find about $10 \mathrm{mU}$ xylose reductase $(\mathrm{mg} \text { protein) })^{-1}$ and $40 \mathrm{mU}$ xylitol dehydrogenase (mg protein $)^{-1}$ in extracts of $R$. toruloides grown on xylose. The question that arises is whether these amounts can account for the observed rate of xylose utilization.

During the last $20 \mathrm{~h}$ of the cultivation on xylose shown in Fig. 1, xylose was consumed at $0.34 \mathrm{~g} \mathrm{l}^{-1} \mathrm{~h}^{-1}$, which is equivalent to about $4 \mu \mathrm{mol} \mathrm{min}{ }^{-1}\left(\mathrm{~g}\right.$ fresh cells) ${ }^{-1}$ (the final cell mass was $3.4 \mathrm{~g}$ dry wt $\mathrm{l}^{-1}$ ). This is four times and twice, respectively, the standard activities of xylose reductase and xylitol dehydrogenase shown in Table 1. For xylitol dehydrogenase, which is unstable, activities up to at least $3 \mathrm{U}(\mathrm{g} \text { fresh } \mathrm{wt})^{-1}$ in xylose-grown cells have been observed during purification from undialysed cell extracts (see Methods). Xylose reductase has a $K_{\mathrm{m}}$ of about $0 \cdot 2 \mathrm{M}$-xylose, so that if the xylose concentration in the cells approaches that in the medium (at $80 \mathrm{~h}, 2.8 \% \equiv 0.18 \mathrm{M}$ ), the activity of xylose reductase would reach $3.2 \mathrm{U}$ (g fresh cells) ${ }^{-1}$. Nevertheless, the known cellular contents of xylose reductase and xylitol dehydrogenase are, at best, only just adequate to explain the observed rates of xylose utilization. These enzymes must limit the rate of growth on xylose, unless there is an alternative pathway. C. utilis appears to contain xylose isomerase as well as the oxidoreductive pathway, but, as mentioned above, work in this laboratory has not been able to demonstrate xylose isomerase in $R$. toruloides. Furthermore, the original work (Höfer et al., 1971) describing this enzyme in $R$. toruloides gave no indication of how much was present.

The xylitol dehydrogenase purified from $R$. toruloides appears to be a tetramer of $45 \mathrm{kDa}$ subunits, similar to the enzyme from $P$. tannophilus (Bolen et al., 1986). Its rapid inactivation by exposure to EDTA suggests it may contain essential metal. The tetrameric 'long chain' alcohol/polyol dehydrogenases (Jörnvall et al., 1987), which include liver sorbitol dehydro- 
genase, typically have zinc at their active sites. Like the xylitol dehydrogenases from the yeasts Candida albicans (Veiga et al., 1968b) and P. tannophilus (Morimoto et al., 1986), the enzyme from $R$. toruloides oxidized D-sorbitol and ribitol at comparable but somewhat smaller rates than xylitol and had little or no activity towards D-arabitol, D-mannitol and erythritol. These enzymes show little or no activity with NADP, and have alkaline $\mathrm{pH}$ optima for xylitol oxidation. The $K_{\mathrm{m}}$ for xylitol of the $P$. tannophilus enzyme is reported to be $11 \mathrm{mM}$ at pH 9.5 (Morimoto et al., 1986) and $70 \mathrm{~mm}$ at pH 7.0 (Ditzelmüller et al., 1984b). We do not know whether the $K_{\mathrm{m}}$ for xylitol of the $R$. toruloides enzyme ( $19 \mathrm{mM}$ at $\mathrm{pH} 8.5$; Fig. $4 b$ ) is markedly dependent on $\mathrm{pH}$. If, like most pyridine-nucleotide-linked dehydrogenases, xylitol dehydrogenase operates by a ternary complex mechanism, then an increase in the apparent $K_{\mathrm{m}}$ for xylitol is expected at sufficiently small $\mathrm{NAD}^{+}$concentrations. Within experimental error, no change was detected between $1 \mathrm{mM}$ and $0.3 \mathrm{~mm}-\mathrm{NAD}$ (Fig. $4 b$ ), suggesting that even at as little as $20 \mu \mathrm{m}-\mathrm{NAD}$ the apparent $K_{\mathrm{m}}$ will still be below $40 \mathrm{~mm}$-xylitol (the value calculated by assuming a $5 \%$ increase in $K_{\mathrm{m}}$ between $1 \mathrm{~mm}$ and $0.3 \mathrm{~mm}-\mathrm{NAD}$ ). Thus, at least at pH $8 \cdot 5$, the apparent $K_{\mathrm{m}}$ for xylitol is not much greater than the probable concentration of xylitol in vivo, which appears to reach $14 \mathrm{mM}$ during growth on xylose (see Results). The Hofstee plot for NAD ${ }^{+}$in Fig. 4(a) is slightly convex towards the origin. $K_{\mathrm{m}}$ values of 0.45 and $0.22 \mathrm{~mm}-\mathrm{NAD}^{+}$, respectively, can be obtained (not shown) from the data above and below $0.4 \mathrm{~mm}-\mathrm{NAD}^{+}$. A much greater dependency of the $K_{\mathrm{m}}$ for NAD on NAD concentration has been reported for the xylitol dehydrogenase from $P$. pullulans, with limiting $K_{\mathrm{m}}$ values for NAD ${ }^{+}$of $1.1 \mathrm{mM}$ and $0.14 \mathrm{~mm}$ (Sugai \& Veiga, 1981). Although mild negative cooperativity cannot be excluded, a more likely explanation is that the purified enzyme is a mixture of slightly different molecules, possibly, for example, with different zinc contents.

Enzymes with xylitol dehydrogenase activity but different patterns of substrate specificity have been reported in two other yeasts. Pullularia pullulans contains an enzyme that is inactive with D-sorbitol (of eight polyols tested, only xylitol and ribitol were oxidized; Sugai \& Veiga, 1981), whereas Candida boidinii contains an enzyme which is 7- to 18-fold more active with D-mannitol, D-sorbitol or ribitol than with xylitol (Vongsuvanlert \& Tani, 1988a). The Dmannitol dehydrogenase of $R$. toruloides is distinct from the major xylitol dehydrogenase (see Results), and since it is present in glucose-grown cells (not shown), extracts of which cannot oxidize xylitol, its activity towards xylitol must be small.

The NADPH-linked xylose reductase found in $R$. toruloides was much more active with DLglyceraldehyde than with xylose. The preparation studied was not pure, but the ratio of activities towards DL-glyceraldehyde and xylose (16 at $33 \mathrm{~mm}$ substrate) did not change during the partial purification. Several yeasts, including Rhodotorula sp. (Watson et al., 1969), P. stipitis (Verduyn et al., 1985) and $P$. tannophilus (Ditzelmüller et al., 1984a) contain NADPH-linked aldose reductases with a similar preference for glyceraldehyde to xylose. These enzymes catalyse the reverse reaction only slowly and at high pH (Sheys \& Doughty, 1971; Verduyn et al., 1985), and with our preparation the reverse reaction could not be detected. It seems to be characteristic of yeasts that can use xylose with limited oxygen supply that they contain (also) NADH-linked xylose reductase, apparently to maintain the redox balance (Bruinenberg et al., 1984). $R$. toruloides cannot grow anaerobically, and we could detect no NADH-linked xylose reductase.

In conclusion, we have shown that xylose-grown $R$. toruloides contains both xylose reductase and xylitol dehydrogenase and grows as rapidly on xylitol as xylose, and with a shorter lag phase. Conversion of xylose to xylulose by these enzymes is likely to play a major role in the aerobic utilization of xylose by this yeast.

We thank Dr Paula Kristo for her interest in this work. We are grateful to Kaija Konttinen MSc and Leena Oinonen for performing the HPLC analyses and to Sirkka Kanervo for technical assistance.

\section{REFERENCES}

Bicho, P. A., Runnals, P. L., Cunningham, J. D. \& LEE, H. (1988). Induction of xylose reductase and xylitol dehydrogenase activities in Pachysolen tannophilus and Pichia stipitis on mixed sugars. Applied and Environmental Microbiology 54, 50-54.
Bolen, P. L. Roth, K. A. \& Freer, S. N. (1986). Affinity purifications of aldose reductase and xylitol dehydrogenase from the xylose-fermenting yeast Pachysolen tannophilus. Applied and Environmental Microbiology 52, 660-664. 
BradFord, M. M. (1976). A rapid and sensitive method for the quantitation of microgram quantities of protein utilizing the principle of protein-dye binding. Analytical Biochemistry 72, 248-254.

BruinenberG, P. M., DE Bot, P. H. M., VAN DiJKeN, J. P. \& Scheffers, W. A. (1984). NADH-linked aldose reductase: the key to anaerobic alcoholic fermentation of xylose by yeasts. Applied Microbiology and Biotechnology 19, 256-260.

ChIANG, C. \& KNIGHT, S. G. (1960). Metabolism of Dxylose by moulds. Nature, London 188, 79-81.

Ditzelmüller, G., KubiceK, C. P., Wöhrer, W. \& RöHR, M. (1984a). Xylose metabolism in Pachysolen tannophilus: purification and properties of xylose reductase. Canadian Journal of Microbiology 30, 1330-1336.

Ditzelmüller, G., KubiceK, C. P., Wöhrer, W. \& RöHR, M. (1984b). Xylitol dehydrogenase from Pachysolen tannophilus. FEMS Microbiology Letters 25, 195-198.

Eisenthal, R. \& CoRnish-Bowden, A. (1974). The direct linear plot. A new graphical procedure for estimating enzyme kinetic parameters. Biochemical Journal 139, 715-720.

HÖFER, M., BETZ, A. \& KoTYK, A. (1971). Metabolism of the obligatory aerobic yeast Rhodotorula gracilis. IV. Induction of an enzyme necessary for D-xylose catabolism. Biochimica et biophysica acta 252, 1-12.

Horitsu, H. \& TOMOEDA, M. (1966). Pentose metabolism by Candida utilis. III. Polyol: NAD oxidoreductase. Agricultural and Biological Chemistry 30, 962966.

Horitsu, H., Tomoeda, M. \& Kumagai, K. (1968). Pentose metabolism in Candida utilis. IV. NADP specific polyol dehydrogenase. Agricultural and Biological Chemistry 32, 514-517.

Jörnvall, H., Persson, B. \& Jeffery, J. (1987). Characteristics of alcohol/polyol dehydrogenases. The zinc-containing long-chain alcohol dehydrogenases. European Journal of Biochemistry 167, 195-201.

LAEMMLI, U. K. (1970). Cleavage of structural proteins during the assembly of the head of bacteriophage T4. Nature, London 227, 680-685.

Morimoto, S., Matsuo, M., Azuma, K. \& Sinskey, A. J. (1986). Purification and properties of D-xylulose reductase from Pachysolen tannophilus. Journal of Fermentation Technology 64, 219-225.

SheYs, G. H. \& DoughtY, C. C. (1971). The reaction mechanism of aldose reductase from Rhodotorula. Biochimica et biophysica acta 242, 523-531.
Smiley, K. L. \& Bolen, P. L. (1982). Demonstration of $\mathrm{D}$-xylose reductase and $\mathrm{D}$-xylitol dehydrogenase in Pachysolen tannophilus. Biotechnology Letters 4, 607610.

Sugai, J. K. \& Veiga, L. A. (1981). Purification and properties of the xylitol dehydrogenase from Pullularia pullulans. Anais da Academia brasileira de ciencias 53, 183-193.

SugaI, J. K. \& VeIGA, L. A. (1988). Induction of the xylitol dehydrogenase of Pullularia pullulans. Canadian Journal of Microbiology 34, 107-111.

Suihko, M.-L., Suomalainen, I. \& ENari, T.-M. (1983). D-Xylose catabolism in Fusarium oxysporum. Biotechnology Letters 5, 525-530.

TOMOYEDA, M. \& Horitsu, H. (1964). Pentose metabolism by Candida utilis. I. Xylose isomerase. Agricultural and Biological Chemistry 28, 139-143.

VeigA, L. A. (1968a). Polyol dehydrogenases in Candida albicans. I. Reduction of D-xylose to xylitol. Journal of General and Applied Microbiology 14, 6578.

Veiga, L. A. (1968b). Polyol dehydrogenases in Candida albicans. II. Xylitol oxidation to D-xylulose. Journal of General and Applied Microbiology 14, 7987.

Verduyn, C., VAN KLeef, R., Frank, J., JZN, Schreuder, H., van DiJken, J. P. \& Scheffers, W. A. (1985). Properties of the NAD(P)H-dependent xylose reductase from the xylose-fermenting yeast Pichia stipitis. Biochemical Journal 226, 669-677.

VongSuVANLeRT, V. \& TANI, Y. (1988a). Characterization of $\mathrm{D}$-sorbitol dehydrogenase involved in Dsorbitol production of a methanol yeast, Candida boidinii (Kloeckera sp.) no. 2201. Agricultural and Biological Chemistry 52, 419-426.

VONGSUVANLERT, V. \& TANI, Y. (1988b). Purification and characterization of xylose isomerase of a methanol yeast, Candida boidinii, which is involved in sorbitol production from glucose. Agricultural and Biological Chemistry 52, 1817-1824.

WARBURG, O. \& Christian, W. (1941). Isolierung und kristallisation des Gärungsferments Enolase. Biochemische Zeitschrift 310, 384-421.

Watson, J. A., Hayashi, J. A., Schuytema, E. \& Doughty, C. C. (1969). Identification of reduced nicotinamide adenine dinucleotide phosphatedependent aldehyde reductase in a Rhodotorula strain. Journal of Bacteriology 100, 110-116. 